\title{
Lactobacillus fermentum CQPC07 attenuates obesity, inflammation and dyslipidemia by modulating the antioxidant capacity and lipid metabolism in high-fat diet induced obese mice
}

Ya Wu ${ }^{1,2,3,4+}$, Xueya $\mathrm{Li}^{5+}$, Fang Tan ${ }^{6}$, Xianrong Zhou ${ }^{1,2,3}$, Jianfei Mu ${ }^{1,2,3}$ and Xin Zhao ${ }^{1,2,3^{*}}$

\begin{abstract}
Background: Obesity is an epidemic disease in the world, the treatment and prevention of obesity methods have gained great attention. Lactobacillus is the main member of probiotics, and the physiological activity of it is specific to different strains. This study systematically explored the anti-obesity effect and possible mechanism of Lactobacillus fermentum CQPC07 (LF-CQPC07), which was isolated from pickled vegetables.

Results: LF-CQPC07 effectively controlled the weight gain of mice caused by a high-fat diet. The results of pathological sections indicated that LF-CQPCO7 alleviated hepatocyte damage and fat accumulation in adipocytes. The detection of biochemical indictors revealed that LF-CQPC07 decreased the levels of total cholesterol (TC), lowdensity lipoprotein cholesterol (LDL-C), and triglycerides (TG), and increased the level of high-density lipoprotein cholesterol (HDL-C). Additionally, LF-CQPC07 caused the decrease in the amounts of inflammatory cytokines interleukin (IL)-1 $\beta$, tumor necrosis factor-a (TNF- $a$ ), IL-6, and interferon- $\gamma$ (IFN- $\gamma$ ), and the increase in the amounts of the anti-inflammatory cytokines IL-10 and IL-4. LF-CQPC07 also decreased the amounts of alanine aminotransferase (ALT), aspartate transaminase (AST), and alkaline phosphatase (ALP). Confirmed by qPCR, LF-CQPCO7 enhanced the mRNA expression of catalase (CAT), gamma glutamylcysteine synthetase 1 (GSH1), copper/zinc superoxide dismutase (SOD1), manganese superoxide dismutase (SOD2), and glutathione peroxidase (GSH-Px). It also increased the mRNA expression levels of carnitine palmitoyltransferase 1 (CPT1), peroxisome proliferator-activated receptor alpha (PPAR-a), lipoprotein lipase (LPL), and cholesterol 7 alpha hydroxylase (CYP7A1), and decreased that of PPAR- $\gamma$ (Continued on next page)
\end{abstract}

\footnotetext{
* Correspondence: zhaoxin@cque.edu.cn

†Y Wu and Xueya Li are co-first authors and contributed equally to this work.

${ }^{1}$ Chongqing Collaborative Innovation Center for Functional Food, Chongqing University of Education, Xuefu Main Street 9 Nan'an District, Chongqing 400067, People's Republic of China

${ }^{2}$ Chongqing Engineering Research Center of Functional Food, Chongqing University of Education, Xuefu Main Street 9 Nan'an District, Chongqing 400067, People's Republic of China

Full list of author information is available at the end of the article
}

C C The Author(s). 2021 Open Access This article is licensed under a Creative Commons Attribution 4.0 International License, which permits use, sharing, adaptation, distribution and reproduction in any medium or format, as long as you give appropriate credit to the original author(s) and the source, provide a link to the Creative Commons licence, and indicate if changes were made. The images or other third party material in this article are included in the article's Creative Commons licence, unless indicated otherwise in a credit line to the material. If material is not included in the article's Creative Commons licence and your intended use is not permitted by statutory regulation or exceeds the permitted use, you will need to obtain permission directly from the copyright holder. To view a copy of this licence, visit http://creativecommons.org/licenses/by/4.0/. The Creative Commons Public Domain Dedication waiver (http://creativecommons.org/publicdomain/zero/1.0/) applies to the data made available in this article, unless otherwise stated in a credit line to the data. 
(Continued from previous page)

and CCAAT/enhancer binding protein alpha (C/EBP-a) in the liver of mice.

Conclusion: This research confirmed that LF-CQPC07 is capable of ameliorating obesity, improving hyperlipemia, and alleviating chronic low-grade inflammation and liver injury accompanied with obesity. Its mechanism may be the regulation of antioxidant capacity and lipid metabolism. Therefore, LF-CQPCO7 has enormous potential to serve as a potential probiotic for the prevention or treatment of obesity.

Keywords: Lactobacillus fermentum, Anti-inflammation, High-fat diet, Anti-obesity, Lipid metabolism

\section{Introduction}

A high-fat diet has become the common diet in today's society [1], and it can lead to fat accumulation that then develops into obesity. Obese people often present with the comorbidities of dyslipidemia, oxidative stress, insulin resistance, and systemic chronic low-grade inflammation [2]. Therefore, in those who are obese, there are risks for developing numerous diseases, such as type 2 diabetes [3], hyperlipidemia, coronary atherosclerosis [4], non-alcoholic fatty liver [5], and cancer [6]. According to 2016 World Health Organization statistics, more than 1.9 billion adults worldwide are overweight, and over 650 million of them are obese [7]. It is of great significance to study the available strategy that can assist with preventing and treating obesity caused by a high-fat diet.

Recent studies have shown that gut microbes are closely related to obesity, and they also play an important role in body metabolism [8]. The gut microbes play an important role in regulating energy metabolic balance, but a high-fat diet caused imbalance to change the composition of gut microbes $[9,10]$. Moreover, the metabolites of the colonized gut microbiota, such as shortchain fatty acids and lipopolysaccharides, also occupy a very important position in the process of obesity by affecting lipid metabolism, energy metabolism, inflammation, and appetite [11-13]. Thus, it is considerable that changing the gut microbiota can be used as a preventive and therapeutic means for the treatment of obesity.

Probiotics are beneficial to health because they optimize the host's microecological balance, and they are widely used in food and medicine [14]. Lactic acid bacteria screened from fermented foods such as yogurt and pickles are used as probiotics $[15,16]$. Among the edible probiotics, most are lactobacillus, which has excellent adhesion and colonization characteristics [17], regulates the gut microbiota [18], protects the intestinal mucosa [19], and regulates immunity [20]. Thereby, it shows various physiological activities, such as anti-colitis, antiarthritis, anti-constipation, and anti-hypercholesteremia [21-24]. Many studies have shown that dietary supplementation of lactobacillus has an anti-obesity effect [25, 26], but there is specificity between different strains. Therefore, it is crucial to investigate the health benefits of different strains and enrich the variety of probiotics.
In this investigation, we performed experiments with Lactobacillus fermentum CQPC07 (LF-CQPC07) obtained from pickles and explored the effect of it on highfat-diet-induced obesity in mice. Body weight, histopathological sections, and related biochemical indicators were examined to evaluate the anti-obesity, hypolipidemic, anti-inflammatory, and hepatoprotective effects of LF-CQPC07. The mRNA expression was examined by qPCR to explore the possible mechanism of anti-obesity. This project provides new ideas for preventing and treating obesity.

\section{Results}

\section{Effect of LF-CQPC07 on mouse body weight}

Before the experiment, no significant difference was observed in body weight between the groups $(P>0.05)$. The body weight of the model group rapidly increased in the last four weeks, while that of the normal group and treatment groups slowly increased (Fig. 1 and Table. 1). After the experiment, significance was found between the model group and other groups $(P<0.05)$, but there was no significant difference between the normal group and the treatment groups $(P>0.05)$, indicating that LF-CQPC07 had the positive effect of weight control.

\section{Liver and epididymal fat indexes}

As the main metabolic organ, the liver weight reflects fat storage in mice to a certain extent. As shown in Table 2, compared with the model group, other groups' liver indexes were decreased to a varying degree $(P<0.05)$, and those of mice in the LF-CQPC07-H group were similar to those in the normal group.

Epididymal fat is white adipose tissue, and its organ index partly reflects the storage of adipose in mice [27]. Table 2 showed that there was significance between the model group and other groups $(\mathrm{P}<0.05)$. The high concentration of LF-CQPC07 significantly reduced the epididymal fat index, which is the smallest in treatment groups.

\section{Histopathological examination of the liver and epididymal fat}

As shown in Fig. 2a, the hepatocytes in mice of the normal group exhibited a complete cellular morphology, 


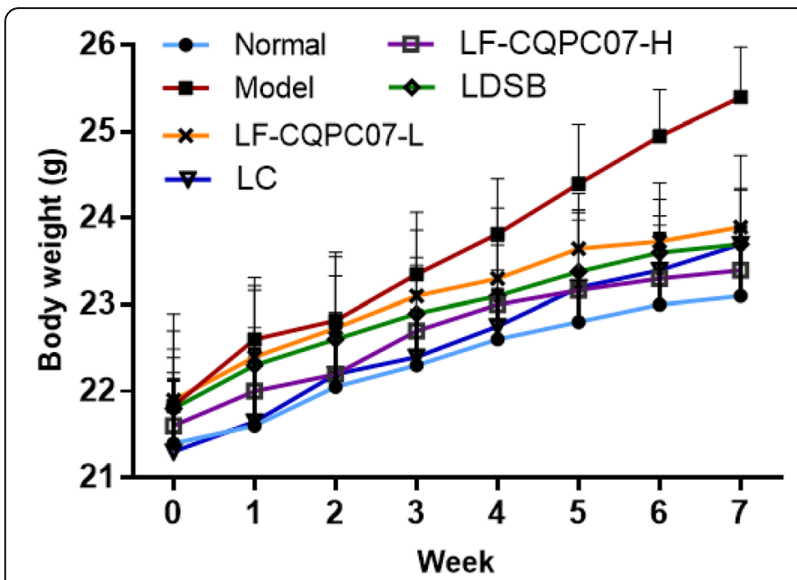

Fig. 1 Body weight of mice during the experiment. The data are shown as mean \pm SD $(n=10)$. LC: mice treated with $200 \mathrm{mg} / \mathrm{kg} \mathrm{L-}$ carnitine: LDSB: mice treated with Lactobacillus delbruechii subsp. bulgaricus $\left(1.0 \times 10^{9} \mathrm{CFU} / \mathrm{kg}\right)$; LF-CQPC07-L: mice treated with Lactobacillus fermentum CQPC07 $\left(1.0 \times 10^{8} \mathrm{CFU} / \mathrm{kg}\right)$; LF-CQPC07-H: mice treated with Lactobacillus fermentum CQPC07 $\left(1.0 \times 10^{9} \mathrm{CFU} / \mathrm{kg}\right)$

and they surrounded the central vein in a radial arrangement without obvious fat vacuoles. In contrast, the central vein of liver tissue in the model group was obviously destroyed. Besides, the hepatocytes were arranged in a disorderly fashion, and many fat vacuoles were visible. In contrast with the model group, the number of fat vacuoles in the LF-CQPC07-H groups was significantly reduced, and hepatocytes were closely arranged.

It was evident that the adipocytes of mice in the model group were larger than those in the normal group (Fig. $2 \mathrm{~b})$, in which the adipocytes were tightly ordered with uniform cell size. The adipocytes in the treatment group were significantly smaller than those in the model group, and most of they were relatively uniform in size. In all treatment groups, the adipocytes in LF-CQPC07-H group were similar to those in the normal groups.

\section{The TC, TG, LDL-C, HDL-C, ALP, ALT, and AST levels in} serum of mice

From Fig. 3, an increase in the serum TC, TG, and LDL levels, and a decrease in HDL-C levels were detected in the mice of the model group when compared with the normal group $(P<0.05)$. LF-CQPC07, L-carnitine, and LDSB significantly reduced serum TC, TG, and LDL levels and increased serum HDL-C levels $(P<0.05)$. The treatment effect of high concentrations of LF-CQPC07 was more optimal than that of LDSB $(\mathrm{P}<0.05)$, and similar to that of the L-carnitine group.

The ALT, AST, and ALP levels in serum are important indicators for determining the degree of liver injury. As shown in Fig. 4, the serum ALT, AST, and ALP levels in mice of the model group were higher than those of the normal group $(P<0.05)$. After treatment, serum ALT, AST, and ALP levels were decreased to varying degrees. Compared with the model group, the content of ALT, AST, and ALP in the LF-CQPC07-H and L-carnitine groups was significantly reduced $(P<0.05)$, and was lower than those in the LDSB group $(\mathrm{P}<0.05)$.

\section{Mouse serum cytokine TNF- $\alpha$, IFN- $\gamma$, IL-6, IL-1 $\beta$, IL-4, and IL-10 levels}

The results (Fig. 5 and Fig. 6) revealed that the mouse serum levels of anti-inflammatory cytokines IL-4 and IL10 were significantly reduced in the model group, and inflammatory cytokines IL- 6 , IFN- $\gamma$, TNF- $\alpha$, and IL- $1 \beta$ were significantly increased compared with the normal group $(P<0.05)$. After the intervention, the mouse serum levels of IL-4 and IL-10 were significantly increased, and IL-6, IL-1 $\beta$, TNF- $\alpha$, and IFN- $\gamma$ levels were significantly reduced in the L-carnitine and the LFCQPC07-H groups $(\mathrm{P}<0.05)$. It was obvious that $\mathrm{L}-$ carnitine and LF-CQPC07-H resulted in more normalization of parameters than LDSB and LFCQPC07-L.

Table 1 The body weight of mice during the experiment

\begin{tabular}{lllllll}
\hline Time (Week) & $\begin{array}{l}\text { Normal } \\
(\mathbf{g})\end{array}$ & $\begin{array}{l}\text { Model } \\
\mathbf{( g )}\end{array}$ & $\begin{array}{l}\text { LF- } \\
\text { CQPC07-L(g) }\end{array}$ & $\begin{array}{l}\text { LF- } \\
\text { CQPC07-H(g) }\end{array}$ & $\begin{array}{l}\text { LDSB } \\
(\mathbf{g})\end{array}$ & $\begin{array}{l}\text { LC } \\
(\mathbf{g})\end{array}$ \\
\hline 0 & $21.4 \pm 0.74^{\mathrm{a}}$ & $21.83 \pm 0.86^{\mathrm{a}}$ & $21.9 \pm 1.05^{\mathrm{a}}$ & $21.6 \pm 0.89^{\mathrm{a}}$ & $21.8 \pm 0.9^{\mathrm{a}}$ & $21.3 \pm 0.92^{\mathrm{a}}$ \\
1 & $21.6 \pm 0.89^{\mathrm{a}}$ & $22.6 \pm 0.62^{\mathrm{a}}$ & $22.4 \pm 0.92^{\mathrm{a}}$ & $22 \pm 0.74^{\mathrm{a}}$ & $22.3 \pm 0.87^{\mathrm{a}}$ & $21.65 \pm 0.76^{\mathrm{a}}$ \\
2 & $22.05 \pm 0.68^{\mathrm{a}}$ & $22.82 \pm 0.79^{\mathrm{a}}$ & $22.73 \pm 0.82^{\mathrm{a}}$ & $22.2 \pm 0.72^{\mathrm{a}}$ & $22.6 \pm 0.73^{\mathrm{a}}$ & $22.2^{\mathrm{a}} \pm 0.62^{\mathrm{a}}$ \\
3 & $22.3 \pm 0.63^{\mathrm{a}}$ & $23.35 \pm 0.72^{\mathrm{b}}$ & $23.1 \pm 0.76^{\mathrm{ab}}$ & $22.7 \pm 0.76^{\mathrm{ab}}$ & $22.9 \pm 0.65^{\mathrm{ab}}$ & $22.4 \pm 0.76^{\mathrm{a}}$ \\
4 & $22.6 \pm 0.57^{\mathrm{a}}$ & $23.82 \pm 0.64^{\mathrm{b}}$ & $23.3 \pm 0.82^{\mathrm{ab}}$ & $23 \pm 0.73^{\mathrm{ab}}$ & $23.1 \pm 0.59^{\mathrm{ab}}$ & $22.75 \pm 0.65^{\mathrm{a}}$ \\
5 & $22.8 \pm 0.59^{\mathrm{a}}$ & $24.4 \pm 0.69^{\mathrm{b}}$ & $23.65 \pm 0.64^{\mathrm{ab}}$ & $23.17 \pm 0.81^{\mathrm{a}}$ & $23.38 \pm 0.72^{\mathrm{a}}$ & $23.2 \pm 0.87^{\mathrm{a}}$ \\
6 & $23 \pm 0.82^{\mathrm{a}}$ & $24.95 \pm 0.54^{\mathrm{b}}$ & $23.73 \pm 0.68^{\mathrm{a}}$ & $23.3 \pm 0.62^{\mathrm{a}}$ & $23.6 \pm 0.62^{\mathrm{a}}$ & $23.4 \pm 0.63^{\mathrm{a}}$ \\
7 & $23.1 \pm 0.79^{\mathrm{a}}$ & $25.4 \pm 0.58^{\mathrm{b}}$ & $23.9 \pm 0.83^{\mathrm{a}}$ & $23.4 \pm 0.53^{\mathrm{a}}$ & $23.7 \pm 0.65^{\mathrm{a}}$ & $23.7 \pm 0.73^{\mathrm{a}}$ \\
\hline
\end{tabular}

The data are shown as mean \pm SD $(n=10)$. ${ }^{\text {ab }}$ Mean values with different letters in the same row are significantly different $(P<0.05)$. LC: mice treated with 200 mg $/$ kg L-carnitine; LDSB: mice treated with Lactobacillus delbruechii subsp. bulgaricus $\left(1.0 \times 10^{9} \mathrm{CFU} / \mathrm{kg}\right)$; LF-CQPC07-L: mice treated with Lactobacillus fermentum CQPC07 $\left(1.0 \times 10^{8} \mathrm{CFU} / \mathrm{kg}\right)$; LF-CQPC07-H: mice treated with Lactobacillus fermentum CQPC07 $\left(1.0 \times 10^{9} \mathrm{CFU} / \mathrm{kg}\right)$ 
Table 2 Liver and epididymal fat indexes of mice in each group

\begin{tabular}{lllllll}
\hline Group & Normal & Model & LF-CQPC07-L & LF-CQPC07-H & LC & LDSB \\
\hline Liver Index & $2.26 \pm 0.15^{\mathrm{b}}$ & $3.83 \pm 0.41^{\mathrm{a}}$ & $3.07 \pm 0.34^{\mathrm{c}}$ & $2.41 \pm 0.21^{\mathrm{bd}}$ & $2.92 \pm 0.31^{\mathrm{ec}}$ & $2.63 \pm 0.17^{\mathrm{ed}}$ \\
$\begin{array}{l}\text { Epididymal } \\
\text { fat index }\end{array}$ & $0.93 \pm 0.08^{\mathrm{b}}$ & $2.08 \pm 0.10^{\mathrm{a}}$ & $1.87 \pm 0.09^{\mathrm{d}}$ & $1.18 \pm 0.07^{\mathrm{e}}$ & $1.49 \pm 0.07^{\mathrm{c}}$ & $1.43 \pm 0.06^{\mathrm{c}}$
\end{tabular}

Values are presented as mean \pm standard deviation (liver Index: $n=10 /$ group, epididymal fat index: $n=5 /$ group). ${ }^{\text {a-e }}$ Mean values with different letters in the same row are significantly different $(P<0.05)$. LC: mice treated with L-carnitine $(200 \mathrm{mg} / \mathrm{kg})$; LDSB: mice treated with Lactobacillus delbruechii subsp. bulgaricus $\left(1.0 \times 10^{9}\right.$ CFU/kg); LF-CQPC07-L: mice treated with Lactobacillus fermentum CQPC07 $\left(1.0 \times 10^{8} \mathrm{CFU} / \mathrm{kg}\right)$; LF-CQPC07-H: mice treated with Lactobacillus fermentum CQPC07 $\left(1.0 \times 10^{9} \mathrm{CFU} / \mathrm{kg}\right)$

A

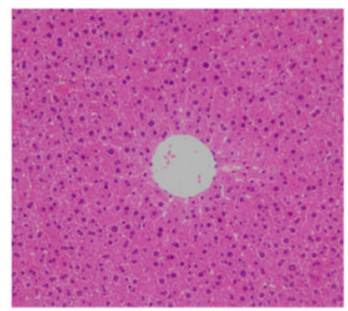

Normal

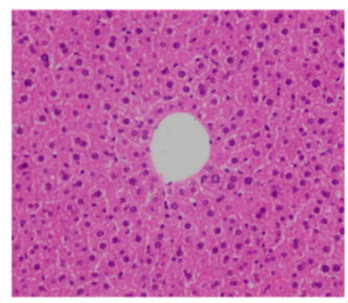

LF-CQPC07-H

B

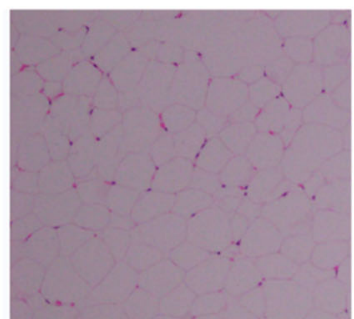

Normal

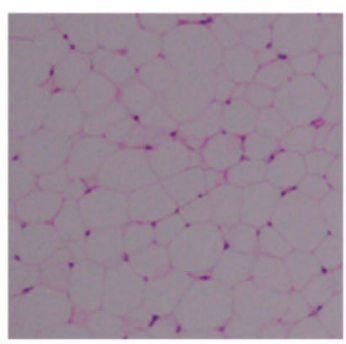

LF-CQPC07-H

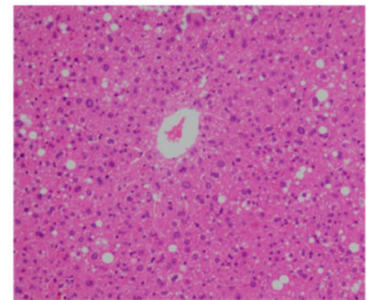

Model

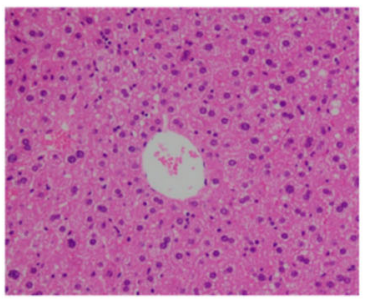

LF-CQPC07-L

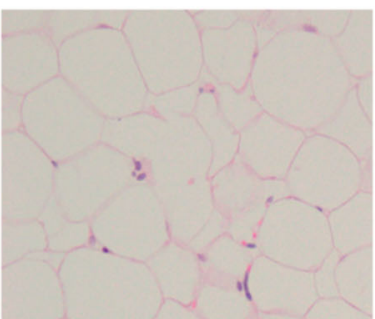

Model

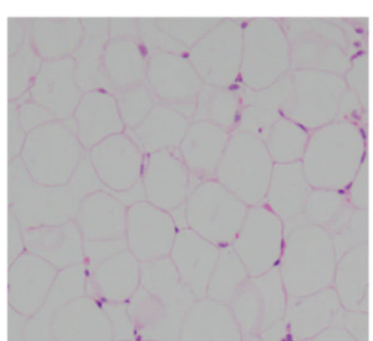

LF-CQPC07-L

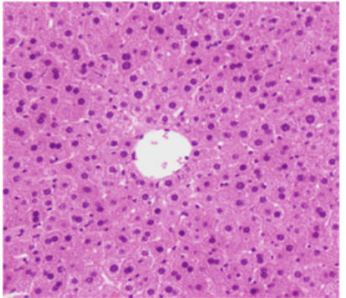

\section{L-Carnitine}

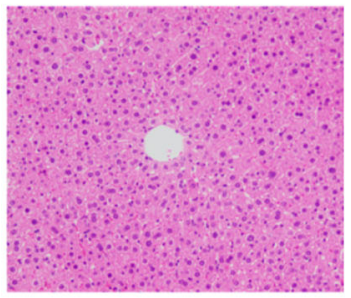

LDSB

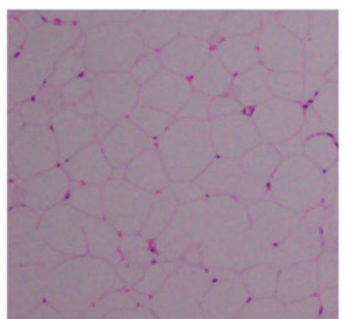

L-Carnitine

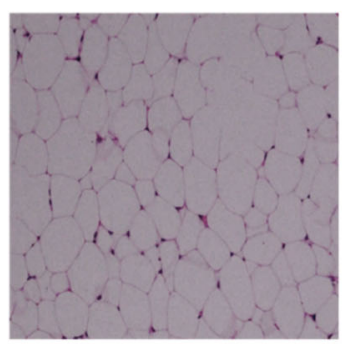

LDSB

Fig. 2 (A) Histopathological observation of liver sections in mice of the different groups after staining with hematoxylin and eosin (H\&E). (B) H\&E histopathological observation of the epididymal fat tissue in mice of the different groups 

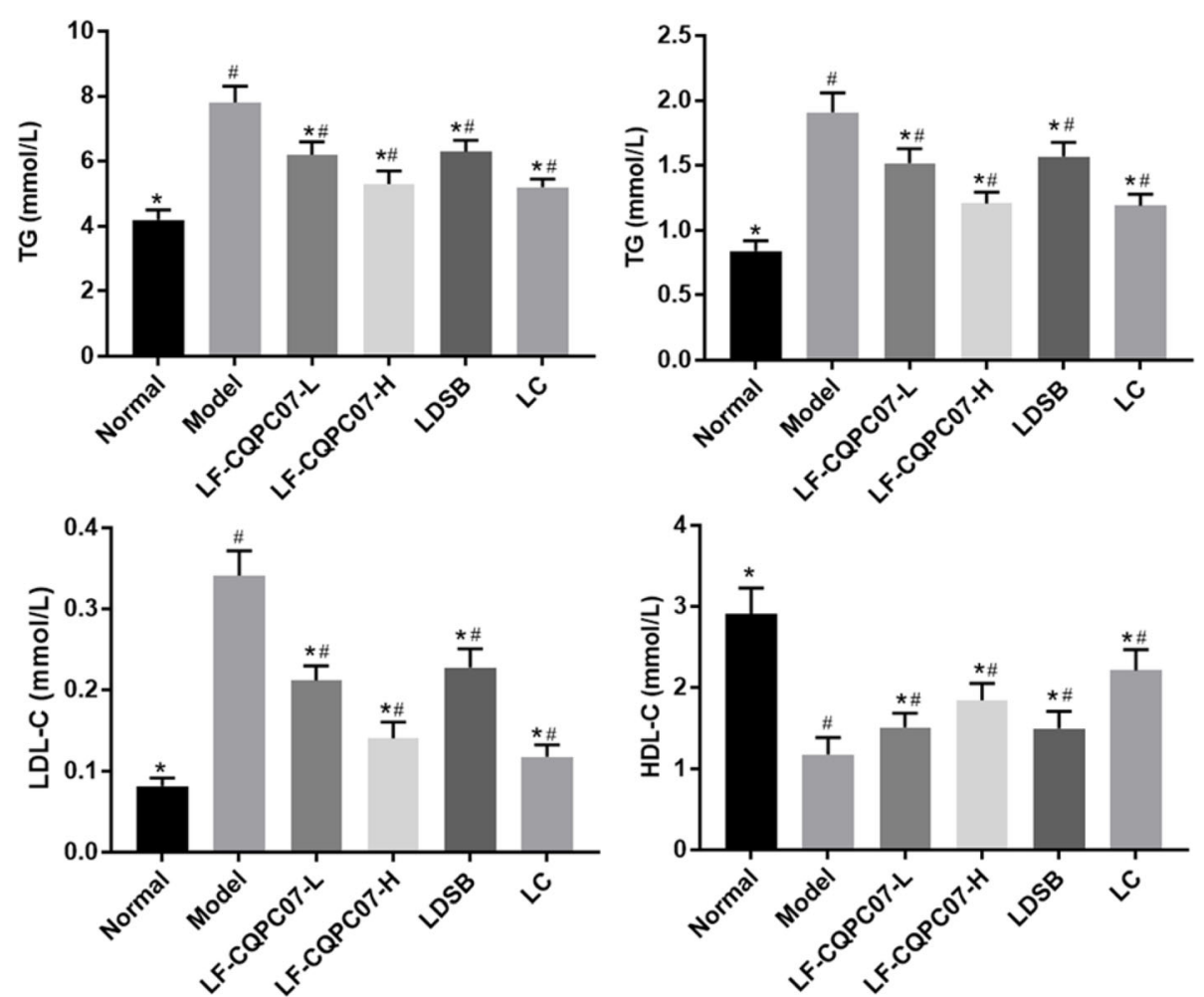

Fig. $3 \mathrm{TC}, \mathrm{TG}, \mathrm{HDL}-\mathrm{C}$, and LDL-C levels in the liver of mice. The data are shown as mean $\pm S D(n=10) .{ }^{*} P<0.05$ vs Model group, ${ }^{\#} \mathrm{P}<0.05$ vs Normal group

SOD1, SOD2, CAT, GSH-Px, and GSH-1 mRNA expression in the liver tissue

Obesity is accompanied by high oxidative stress. Therefore, the mRNA expression of antioxidant-related genes was evaluated to exposit the anti-obesity mechanism of LF-CQPC07. The experimental result (Fig. 7) indicated that the high-sugar and high-fat diet inhibited the mRNA expression levels of antioxidant-related genes SOD1, SOD2, GSH1, CAT, and GSH-Px, those of model group were the lowest among all groups. LF-CQPC07, L-carnitine, and LDSB enhanced the mRNA expression of SOD1, SOD2, GSH1, CAT, and GSH-Px to different degrees compared with the model group $(p<0.05)$. In all treatment groups, the enhancement effect of LFCQPC07-H was notable, and it was obviously better than that of LF-CQPC07-L.

PPAR-,- C/EBP- $\alpha$, PPAR- $\alpha$, LPL, CPT1, and CYP7A1 mRNA expression in the liver tissue

The mRNA expression associated with lipid metabolism was also tested to further explain the anti-obesity mechanism of LF-CQPC07. From Fig. 8, the highest
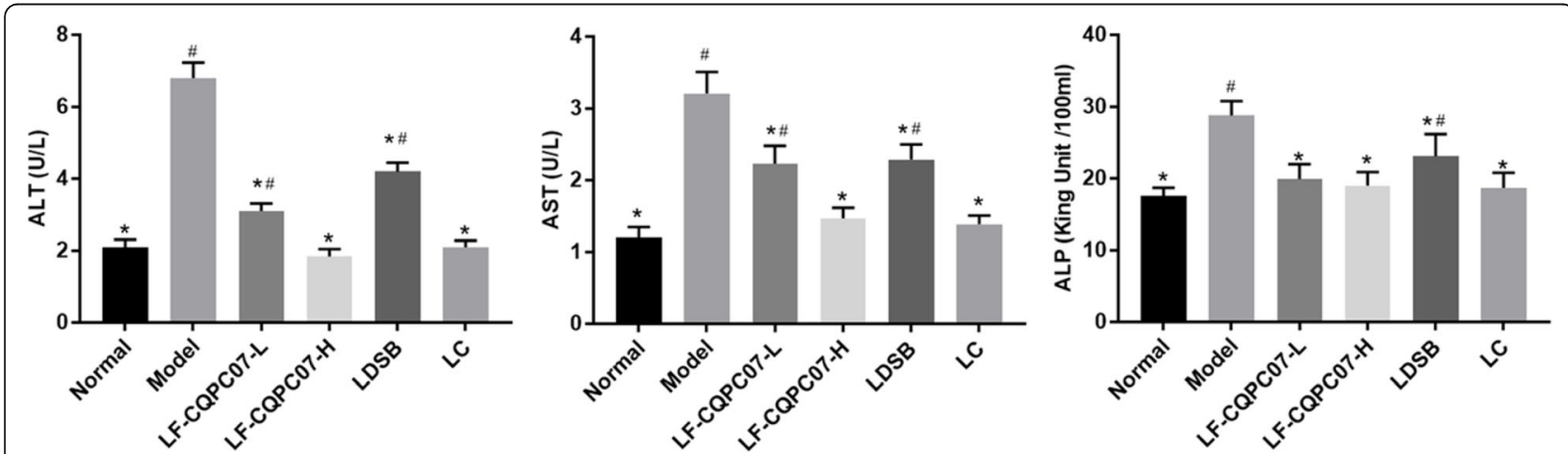

Fig. 4 ALT, AST, and ALP levels in the liver of mice. The data are shown as mean $\pm S D(n=10)$. ${ }^{*} P<0.05$ vs Model group, ${ }^{\#} P<0.05$ vs Normal group 

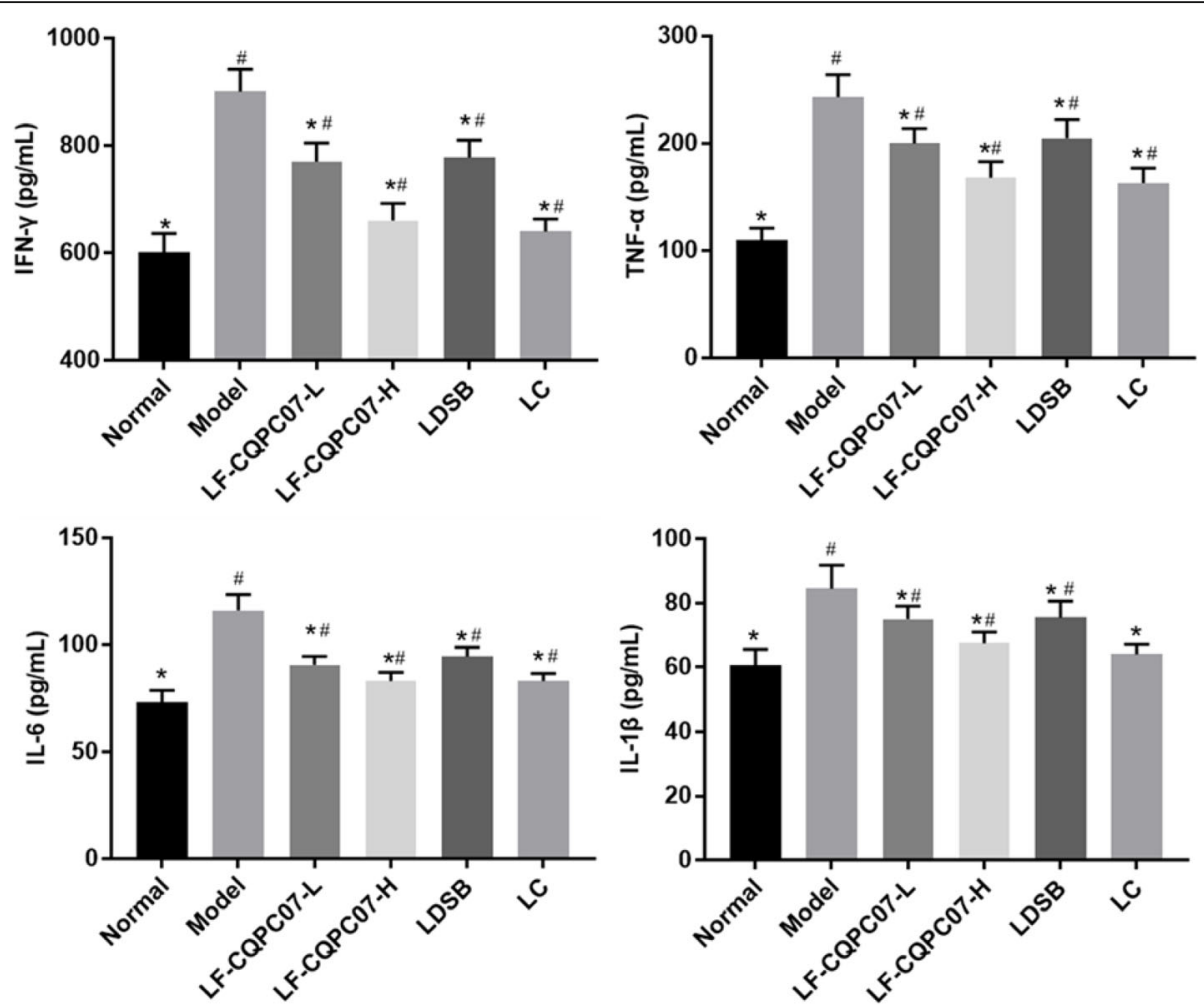

Fig. 5 Serum levels of the cytokines TNF-a, IFN- $\gamma, I L-1 \beta$, and IL-6 in mice. The data are shown as mean $\pm S D(n=10)$. ${ }^{*} P<0.05$ vs Model group, ${ }^{\#} \mathrm{P}<0.05$ vs Normal group

expression levels of PPAR- $\gamma$ and C/EBP- $\alpha$ mRNA, and lowest expression levels of PPAR- $\alpha$, LPL, CPT1, and CYP7A1 mRNA were observed in the model group $(P<$ $0.05)$. After treatment with different programs, LFCQPC07-H was the most prominent in upregulating the mRNA expression of PPAR- $\alpha$, LPL, CPT1, and CYP7A1 and downregulating the mRNA expression of PPAR- $\gamma$ and $\mathrm{C} / \mathrm{EBP}-\alpha$, which is presented as a dose-dependent relationship.

\section{Discussion}

Obesity is a chronic metabolic disease that endangers health worldwide, and features disorders of lipid metabolism, insulin resistance, and chronic low-grade inflammation [2]. The high-fat diet is an environmental factor that can cause obesity by the abnormal accumulation of lipids. Probiotics represented by Lactobacillus and Bifidobacterium could improve the intestinal flora and intestinal mucosal integrity, stimulate the feeling of satiety,
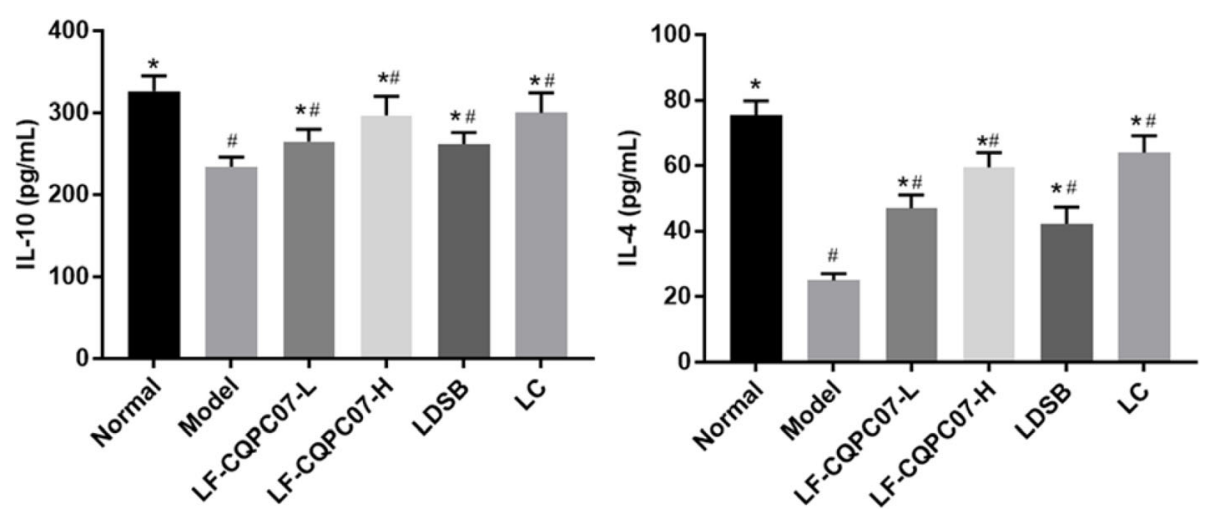

Fig. 6 Serum levels of the cytokines IL-4 and IL-10 in mice. The data are shown as mean \pm SD $(n=10)$. * $P<0.05$ vs Model group, ${ }^{\#} P<0.05$ vs Normal group 

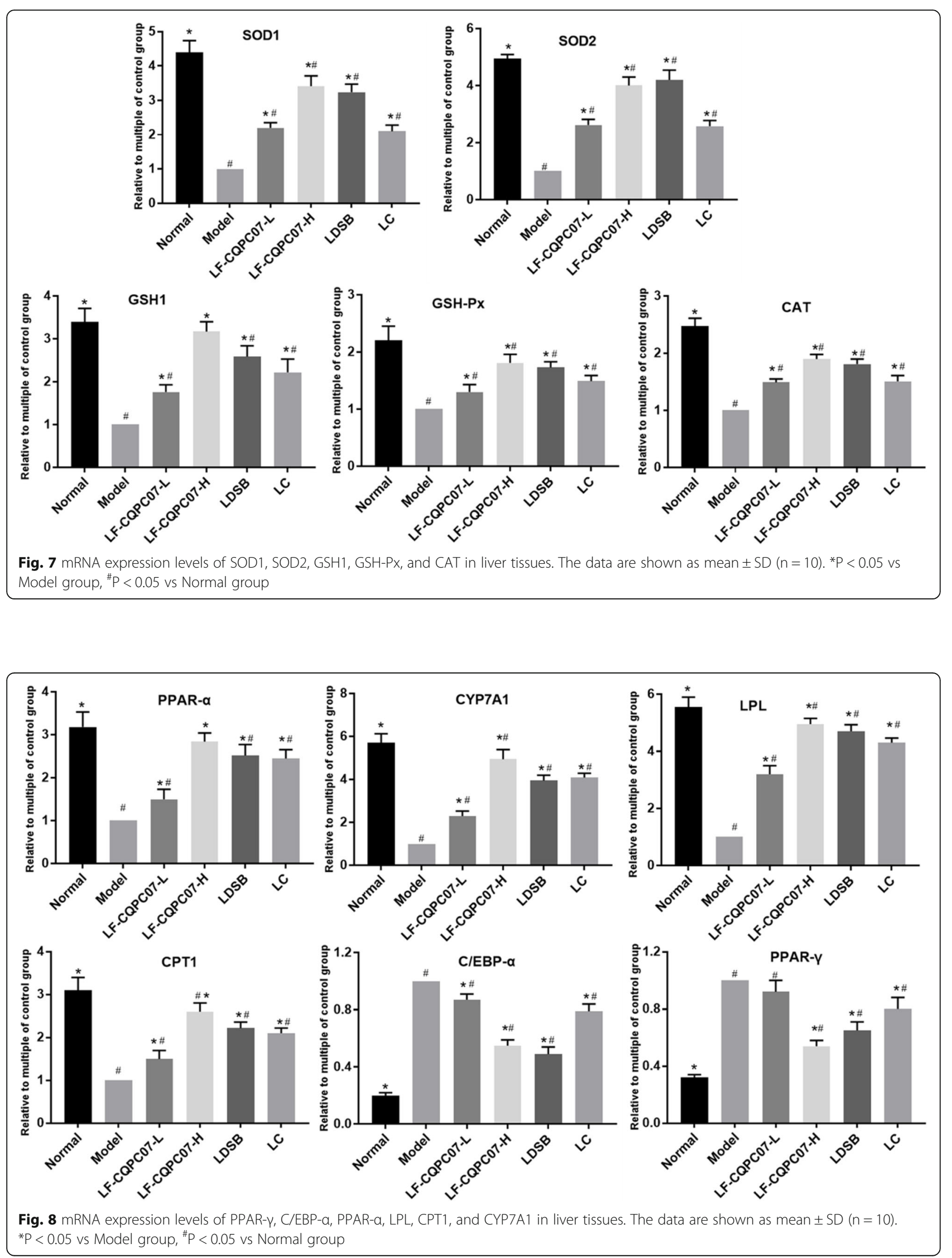
reduce lipopolysaccharide levels, stimulate insulin signal transduction, reduce blood lipids and cholesterol, increase the production of short chain fatty acid and down-regulate the inflammatory signals to alleviate obesity [28-32]. A high-fat diet can significantly increase the weight of mice, but LF-CQPC07 controlled weight gain in mice and the increase in white adipose tissue to achieve the purpose of alleviating obesity.

Excessive lipid accumulation is mainly manifested by the hypertrophy of adipocytes [33, 34]. This leads to endocrine dysfunction, in which there is increased secretion of proinflammatory adipokines, such as TNF- $\alpha$, IL1 , IL-6, and chemokines monocyte chemoattractant protein $[33,34]$. Obesity is accompanied by excessive ROS, which activates the TNF, NF- $\mathrm{BB}$, and JNK signaling pathways to induce apoptosis and inflammation [35-37]. Therefore, obese people are in a chronic low inflammatory state. In the model group, the adipose tissue of mice was significantly hypertrophic compared with other groups, and serum levels of pro-inflammatory cytokines TNF- $\alpha$, IL-6, IL- $1 \beta$, and IFN- $\gamma$ were increased, while anti-inflammatory factors IL-10 and IL-4 levels were decreased. IL-10 and IL-4 are more than anti-inflammatory cytokines, but also inhibit the secretion of proinflammatory cytokines such as IL-2, IFN- $\gamma$, TNF- $\alpha$, IL$1 \beta$, IL-6, IL-8 [38-42]. At the same time, the activities of macrophages, $\mathrm{T}$ cells and other immune cells are regulated by them to suppress the immune response [3842]. Tissue sections showed that LF-CQPC07 alleviates the hypertrophy of adipocytes, and it also significantly reduced the levels of the inflammatory factors TNF- $\alpha$, IL- 6 , IL- $1 \beta$, and IFN- $\gamma$, and increased the levels of antiinflammatory factors IL-10, IL-4, thereby inhibiting chronic low-grade inflammation associated with obesity.

Obesity can be complicated with lipid metabolic disorders that are characterized by an increase in TC, TG, and LDL-C and a decrease in HDL-C. It is also the main cause of endovascular disease [43]. In the model group, the mice were in a lipid metabolic disorder. After intragastric administration of LF-CQPC07, the HDL-C level was increased, and the TC, TG and LDL-C levels were decreased. This showed that LF-CQPC07 relieved the disorder of lipid metabolism caused by a high-fat diet.

The liver is an important metabolic organ. Lipid metabolic disorders, oxidative stress, and inflammation lead to hepatocyte injury [44]. From the results of the liver tissue sections and ALT, AST, and ALP levels [45], which are the clinical indicators of liver function, it was revealed that the hepatocytes of mice in the model group were damaged. The experimental results revealed that LF-CQPC07 relieved hepatocyte injury, and decreased the levels of ALT, AST, and ALP.
Obese people often undergo oxidative stress [36]. The system that defends against oxidative stress is mainly composed of enzymatic and non-enzymatic antioxidants such as CAT, GSH-Px, SOD, and GSH [46]. SOD scavenges superoxide radicals by means of copper, zinc, and manganese ions as auxiliary groups [46]. CAT directly converts hydrogen peroxide into water and oxygen. The reaction of $\mathrm{H}_{2} \mathrm{O}_{2}$ and $\mathrm{GSH}$ to form $\mathrm{H}_{2} \mathrm{O}$ is catalyzed by GSH-Px [46]. LF-CQPC07 upregulated the mRNA expression of SOD1, GSH-Px, SOD2, CAT, and GSH1 to increase the body's antioxidant capacity and inhibit oxidative stress, thereby relieving liver damage and inflammation caused by obesity.

Studies have reported that lactobacillus could regulate signal transduction to modulate lipid metabolism and immune response, including nuclear factor kappa-B (NF-kB), mitogen-activated protein kinase (MAPK), and lipid metabolism (PPAR pathway) [47-49]. Moreover, the metabolites produced by lactobacillus mainly are short chain fatty acids, such as acetic acid, propionic acid, conjugated linoleic acid, which have beneficial effects on the body $[50,51]$. The peroxisome proliferatoractivated receptor (PPAR) family is widely recognized as a lipid sensor that is involved in regulating lipids, glucose metabolism, and energy metabolism $[52,53]$. The PPAR- $\alpha$ is critical in regulating fatty acid uptake, $\beta$ oxidation of fatty acids, ketogenic effects, bile acid synthesis, and triglyceride conversion [54]. PPAR- $\gamma$ is another member of the PPAR family that is an essential transcription factor in regulating lipid metabolism [55, 56]. It participates in fat metabolism and promotes lipid deposition by regulating the transcription of lipid metabolism-related genes $[55,56]$. In addition, PPAR- $\gamma$ acts as a key factor in early adipocyte differentiation and it promotes the expression of C/EBP- $\alpha$, and then they work together to induce adipocyte differentiation and lipid deposition $[57,58]$.

LPL and CPT1, as downstream target genes for PPAR$\alpha$ and PPAR $-\gamma$ signaling, directly regulate lipid metabolism [55, 59]. LPL is a key rate-limiting enzyme for hydrolyzing triglycerides, and can remove triglyceriderich proteins including very low-density lipoprotein (VLDL), LDL, and chylomicron, and increase HDL levels [60]. As the rate-limiting enzyme for the $\beta$-oxidation of fatty acid, CPT1 catalyzes the synthesis of fatty acyl carnitine [61]. CYP7A1 catalyzes cholesterol transformed into bile acid, so it maintains cholesterol homeostasis and bile acid synthesis [62]. LF-CQPC07 upregulated the mRNA expression of PPAR- $\alpha$, LPL, CPT1, and CYP7A1 and downregulated the mRNA expression of PPAR- $\gamma$ and $\mathrm{C} / \mathrm{EBP}-\alpha$ to inhibit the differentiation and proliferation of adipocytes, promote the $\beta$-oxidation of fatty acid and decomposition of triglyceride and cholesterol, thereby ameliorating obesity and dyslipidemia. 


\section{Conclusion}

In conclusion, we systematically studied the anti-obesity properties of LF-CQPC07. It had the ability to control weight gain, improve dyslipidemia, and relieve chronic low-grade inflammation and liver damage. The mechanism of action may be through the regulation of antioxidant capacity and lipid metabolism. Therefore, LFCQPC07 has great potential to develop as anti-obesity products because of its ability to attenuate obesity and regulate related metabolic symptoms.

\section{Material and methods}

\section{Experimental strain}

The strain Lactobacillus fermentum CQPC07 (LFCQPC07) was isolated from commercially available pickled vegetables in Chongqing City, China, and identified using the NCBI's Basic Local Alignment Search Tool (BLAST). LF-CQPC07 was deposited in the China General Microbiological Culture Collection Center (CGMC C, Beijing, China; CGMCC No. 14956). Lactobacillus delbrueckii subsp. bulgaricus (CGMCC No. 1.16075) was chosen as a comparative strain from the CGMCC.

\section{Animal experiments}

Sixty C57BL/6 J mice (6-week-old, 30 males and 30 females) were obtained from Chongqing Medical University. After acclimating for 1 week, all mice were randomly divided into six groups $(n=10)$, including the (i) normal group, (ii) model group, (iii) L-carnitine group (LC), (iv) Lactobacillus delbrueckii subsp. bulgaricus group(LDSB), (v) low-concentration LF-CQPC07 group (LF-CQPC07-L), and (vi) high-concentration LFCQPC07 group (LF-CQPC07-H). The mice in the normal group were bred with a normal diet and conventional drinking water, while the rest of the groups were bred with a D1249251 high-fat diet and 10\% sugar water. Based on previous research, the low-dose of lactobacillus was $10^{8} \mathrm{CFU} / \mathrm{Kg}$, and the high dose was $10^{9} \mathrm{CFU} / \mathrm{Kg}[63$, 64]. The mice in the LDSB group received $1.0 \times 10^{9}$ $\mathrm{CFU} / \mathrm{kg}$ LDSB by intragastric administration, the mice in LC group were gavaged with $200 \mathrm{mg} / \mathrm{kg} \mathrm{L}$-carnitine, and the mice in LF-CQPC07-L and LF-CQPC07-H groups were gavaged with $1.0 \times 10^{8} \mathrm{CFU} / \mathrm{kg}$ and $1.0 \times 10^{9} \mathrm{CFU} /$ $\mathrm{kg}$ LF-CQPC07 once a day, at 11 o'clock from the first week. All mice were fasted for $16 \mathrm{~h}$ after continuous gavage for 7 weeks, and then killed by cervical dislocation after retro-orbital sinus blood collection was performed. The epididymis fat tissue and liver were removed and weighed. The formula (organ index $(\%)=$ organ mass $(\mathrm{g}) /$ mouse body mass $(\mathrm{g}) \times 100)$ was used to calculate the organ index. Approximately $1 \mathrm{~cm}^{2}$ of liver and epididymis fat tissue were fixed with formalin for further preparation of pathological sections. The remaining tissues were stored at $-80^{\circ} \mathrm{C}$ for subsequent tests.
Determination of serum TC, TG, LDL-C, HDL-C, ALP, AST, and ALT levels in mice

After centrifugation of blood at $4000 \mathrm{rpm}$ for $10 \mathrm{~min}$, the supernatant was collected to afford serum. The serum TC, LDL-C, TG, HDL-C, ALP, AST, and ALT levels of mice were measured in accordance with kit instructions (Nanjing Jiancheng Bioengineering Institute, Nanjing, Jiangsu, China).

\section{Determination of serum cytokines TNF- $a$, IFN- - , IL-6, IL-} $1 \beta$, IL-4, and IL-10 levels in mice

The serum was prepared according to the above method, and then, the levels of the serum cytokines TNF- $\alpha$, IFN$\gamma$, IL-6, IL-1 $\beta$, IL-4, and IL-10 were measured following the kit instructions (Beijing Chenglin Bioscience Limited Company, Beijing, China).

Pathological examination of the liver and epididymal fat Liver or epididymal fat tissues fixed in $10 \%$ formalin were processed by dehydration, embedded in paraffin, sectioned, and stained with hematoxylin and eosin. Then, the pathological changes were assessed via an optical microscope (BX43, Olympus, Tokyo, Japan).

\section{Quantitative PCR (qPCR) assay}

For RNA isolation, $1 \mathrm{~mL}$ RNAzol reagent (Invitrogen, Carlsbad, CA, USA) was added to a liver tissue homogenate to extract the total RNA. The purity and

Table 3 Sequences of primers used in this study

\begin{tabular}{|c|c|}
\hline Gene Name & Sequence \\
\hline$\overline{\text { GAPDH }}$ & $\begin{array}{l}\text { Forward: 5'-ACCCAGAAGACTGTGGATGG-3' } \\
\text { Reverse: 5'-ACACATTGGGGGTAGGAACA-3' }\end{array}$ \\
\hline PPAR-a & $\begin{array}{l}\text { Forward: 5'-CCTCAGGGTACCACTACGGAGT-3' } \\
\text { Reverse: 5'-GCCGAATAGTTCGCCGAA-3' }\end{array}$ \\
\hline PPAR- $\gamma$ & $\begin{array}{l}\text { Forward: 5'-AGGCCGAGAAGGAGAAGCTGTTG - 3' } \\
\text { Reverse: 5'-TGGCCACCTCTTTGCTGTGCTC-3' }\end{array}$ \\
\hline CYP7A1 & $\begin{array}{l}\text { Forward: 5'-AGCAACTAAACAACCTGCCAGTACTA-3' } \\
\text { Reverse: 5'-GTCCGGATATTCAAGGATGCA-3' }\end{array}$ \\
\hline CPT1 & $\begin{array}{l}\text { Forward: 5'-AAAGATCAATCGGACCCTAGACA-3' } \\
\text { Reverse: 5'-CAGCGAGTAGCGCATAGTCA - 3' }\end{array}$ \\
\hline C/EBP- $a$ & $\begin{array}{l}\text { Forward: 5'-TGGACAAGAACAGCAACGAGTAC - 3' } \\
\text { Reverse: 5'- GCAGTTGCCCATGGCCTTGAC-3' }\end{array}$ \\
\hline SOD1 & $\begin{array}{l}\text { Forward: 5'-AGGTCGGTGTGAACGGATTTG-3' } \\
\text { Reverse: 5'-GGGGTCGTTGATGGCAACA-3' }\end{array}$ \\
\hline SOD2 & $\begin{array}{l}\text { Forward: 5'-CAGACCTGCCTTACGACTATGG-3' } \\
\text { Reverse: 5'-CCACCATGTTCTTAGAGTGAGG-3' }\end{array}$ \\
\hline LPL & $\begin{array}{l}\text { Forward: 5'-AGGGCTCTGCCTGAGTTGTA-3' } \\
\text { Reverse: 5'-AGAAATCTCGAAGGCCTGGT-3' }\end{array}$ \\
\hline CAT & $\begin{array}{l}\text { Forward: 5'-GGAGGCGGGAACCCAATAG-3' } \\
\text { Reverse: 5'-GTGTGCCATCTCGTCAGTGAA-3' }\end{array}$ \\
\hline GSH-Px & $\begin{array}{l}\text { Forward: 5'-CCACCGTGTATGCCTTCTCC-3' } \\
\text { Reverse: 5'-AGAGAGACGCGACATTCTCAAT-3' }\end{array}$ \\
\hline GSH1 & $\begin{array}{l}\text { Forward: 5'-GGGTGAAGCACAAGAAAGAAGG-3' } \\
\text { Reverse: 5'-TTGGCTGAGGAGCGAAGA-3' }\end{array}$ \\
\hline
\end{tabular}


concentration of the total RNA were tested via ultramicrospectrophotometry (Nano-100, All for Life Science, Hangzhou, Zhejiang, China), and then it was diluted to $1 \mu \mathrm{g} / \mu \mathrm{L}$. To synthesize cDNA templates, $1 \mu \mathrm{L}$ diluted total RNA was employed according to the reverse transcription kit instructions (Tiangen Biotech Co., Ltd., Beijing, China). A solution of $1 \mu \mathrm{L}$ cDNA template and $10 \mu \mathrm{l}$ SYBR Green PCR Master Mix was mixed with $1 \mu \mathrm{L}$ upstream and downstream primers (Table 3). The solution was processed using the cycling conditions of $95^{\circ} \mathrm{C}$ for $60 \mathrm{~s}$, then 40 cycles of $95^{\circ} \mathrm{C}$ for $15 \mathrm{~s}, 55^{\circ} \mathrm{C}$ for $30 \mathrm{~s}$, and $72{ }^{\circ} \mathrm{C}$ for $30 \mathrm{~s}$, with detection at $95^{\circ} \mathrm{C}$ for $30 \mathrm{~s}$, and $55^{\circ} \mathrm{C}$ for $35 \mathrm{~s}$. This test was carried out on Applied Biosystems StepOnePlus ${ }^{\text {Tw }}$ Real-Time PCR Instrument (Thermo Fisher Scientific Co., Ltd., Massachusetts, USA). The date was analyzed by using StepOne ${ }^{\text {mat }}$ software. To calculate relative gene expression, the $2^{-\Delta \Delta \mathrm{Ct}}$ method was employed in which the housekeeping gene was glyceraldehyde-3phosphate dehydrogenase (GAPDH).

\section{Statistical analysis}

The data were analyzed via SPSS 17.0 and GraphPad Prism 7 statistical software. The experimental results are expressed as the mean \pm standard deviation. Between-group comparisons were tested by one-way analysis of variance (ANOVA). $P<0.05$ was considered statistically significant.

\section{Abbreviations}

LPL: lipoprotein lipase; PPAR-ү: peroxisome proliferator-activated receptor gamma; CPT1: carnitine palmitoyltransferase 1; PPAR-a: peroxisome proliferator-activated receptor alpha; C/EBP-a: CCAAT/enhancer binding protein alpha; CYP7A1: cholesterol 7 alpha hydroxylase; GAPD H: glyceraldehyde-3-phosphate dehydrogenase; HDL-C: high-density lipoprotein cholesterol; TC: total cholesterol; TG: triglycerides; LDL-C: lowdensity lipoprotein cholesterol; ALT: alanine aminotransferase; ALP: alkaline phosphatase; AST: aspartate transaminase; TNF-a: tumor necrosis factor alpha; IL-6: interleukin-6; IFN- $\gamma$ : interferon gamma; IL-1 $\beta$ : interleukin-1 beta; IL10: interleukin-10; IL-4: interleukin-4

\section{Acknowledgments}

None.

\section{Authors' contributions}

YW and XYL performed the majority of the experiments and wrote the manuscript; FT, XRZ and JFM contributed to the data analysis; and XZ designed and supervised the study and checked the final manuscript. The author(s) read and approved the final manuscript.

\section{Funding}

This research was funded by Chongqing University Innovation Research Group Project (CXQTP20033) and the Science and Technology Project of Chongqing Education Commission (KUQN202001604), China.

\section{Availability of data and materials}

The datasets used and/or analyzed during the current study are available from the corresponding author on reasonable request.

\section{Ethics approval and consent to participate}

This study was approved by the Ethics Committee of Chongqing Collaborative Innovation Center for Functional Food (201906040B; Chongqing, China).
Consent for publication

Not applicable.

\section{Competing interests}

The authors declare that they have no conflict of interest.

\section{Author details}

${ }^{1}$ Chongqing Collaborative Innovation Center for Functional Food, Chongqing University of Education, Xuefu Main Street 9 Nan'an District, Chongqing 400067, People's Republic of China. ${ }^{2}$ Chongqing Engineering Research Center of Functional Food, Chongqing University of Education, Xuefu Main Street 9 Nan'an District, Chongqing 400067, People's Republic of China. ${ }^{3}$ Chongqing Engineering Laboratory for Research and Development of Functional Food, Chongqing University of Education, Xuefu Main Street 9 Nan'an District, Chongqing 400067, People's Republic of China. ${ }^{4}$ College of Biological and Chemical Engineering, Chongqing University of Education, Xuefu Main Street 9 Nan'an District, Chongqing 400067, China. ${ }^{5}$ Department of Dermatology, People's Hospital of Chongqing Banan District, 659 Yunan Avenue, Longzhouwan Street, Banan District, Chongqing 401320, China. ${ }^{6}$ Department of Public Health, Our Lady of Fatima University, 838 Valenzuela, Philippines.

Received: 12 July 2020 Accepted: 22 January 2021

Published online: 02 February 2021

References

1. Poutahidis T, Kleinewietfeld M, Smillie C, Levkovich T, Perrotta A, Bhela S, Varian BJ, Ibrahim YM, Lakritz JR, Kearney SM, Chatzigiagkos A, Hafler DA, Alm EJ, Erdman SE. Microbial reprogramming inhibits Western dietassociated obesity. PLoS One. 2013;8:e68596.

2. Bastard JP, Maachi M, Lagathu C, Kim MJ, Caron M, Vidal H, Capeau J, Feve B. Recent advances in the relationship between obesity, inflammation, and insulin resistance. Eur Cytokine Netw. 2006;17:4-12.

3. Khaodhiar L, Cummings S, Apovian CM. Treating diabetes and prediabetes by focusing on obesity management. Curr Diab Rep. 2009;9:348-54.

4. Mozaffarian D. Dietary and policy priorities for cardiovascular disease, diabetes, and obesity: a comprehensive review. Circulation. 2016;133:187-225.

5. Younossi ZM, Koenig AB, Abdelatif D. Global epidemiology of nonalcoholic fatty liver disease-meta-analytic assessment of prevalence, incidence, and outcomes. Hepatology. 2016;64:73-84.

6. Renehan AG, Tyson M, Egger M, Heller RF, Zwahlen M. Body-mass index and incidence of cancer: a systematic review and meta-analysis of prospective observational studies. Lancet. 2008;371:569-78.

7. NCD Risk Factor Collaboration (NCD-RisO). Trends in adult body-mass index in 200 countries from 1975 to 2014: a pooled analysis of 1698 population-based measurement studies with 19.2 million participants. Lancet. 2016;387:1377-1396.

8. Turnbaugh PJ, Ley RE, Mahowald MA, Magrini V, Mardis ER, Gordon JI. An obesity-associated gut microbiome with increased capacity for energy harvest. Nature. 2006:444:1027-31.

9. Jumpertz R, Le DS, Turnbaugh PJ, Trinidad C, Bogardus C, Gordon JI, Krakoff $J$. Energy-balance studies reveal associations between gut microbes, caloric load, and nutrient absorption in humans. Am J Clin Nutr. 2011;94:58-65.

10. Hildebrandt MA, Hoffmann C, Sherrill-Mix SA, Keilbaugh SA, Hamady M, Chen YY, Knight R, Ahima RS, Bushman F, Wu GD. High-fat diet determines the composition of the murine gut microbiome independently of obesity. Gastroenterology. 2009;137:1716-24.e242.

11. Samuel BS, Shaito A, Motoike T, Rey FE, Backhed F, Manchester JK, Hammer RE, Williams SC, Crowley J, Yanagisawa M, Gordon Jl. Effects of the gut microbiota on host adiposity are modulated by the short-chain fatty-acid binding $G$ protein-coupled receptor, Gpr41. Proc Natl Acad Sci U S A. 2008;105:16767-72.

12. Sanz Y, Santacruz A, De Palma G. Insights into the roles of gut microbes in obesity. Interdiscip Perspect Infect Dis. 2008;2008:829101.

13. Baothman OA, Zamzami MA, Taher I, Abubaker J, Abu-Farha M. The role of gut microbiota in the development of obesity and diabetes. Lipids Health Dis. 2016; 15:108.

14. Group F.W.W. Guidelines for the evaluation of probiotics in food. London, ON: FAO/WHO; 2002.

15. Stanton C, Ross RP, Fitzgerald GF, Van Sinderen D. Fermented functional foods based on probiotics and their biogenic metabolites. Curr Opin Biotechnol. 2005;16:198-203. 
16. Yu Z, Zhang X, Li S, Li C, Li D, Yang Z. Evaluation of probiotic properties of Lactobacillus plantarum strains isolated from Chinese sauerkraut. World J Microbiol Biotechnol. 2013;29:489-98.

17. Van Tassell ML, Miller MJ. Lactobacillus adhesion to mucus. Nutrients. 2011;3: 613-36.

18. Palomar MM, Maldonado Galdeano C, Perdigón G. Influence of a probiotic lactobacillus strain on the intestinal ecosystem in a stress model mouse. Brain Behav Immun. 2014;35:77-85.

19. Hou Q, Ye L, Liu H, Huang L, Yang Q, Turner JR, Yu Q. Lactobacillus accelerates ISCS regeneration to protect the integrity of intestinal mucosa through activation of STAT3 signaling pathway induced by LPLS secretion of IL-22. Cell Death Differ. 2018;25:1657-70.

20. Baarlen PV, Wells JM, Kleerebezem M. Regulation of intestinal homeostasis and immunity with probiotic lactobacilli. Trends Immunol. 2013;34:208-15.

21. Bekkali NL, Bongers ME, Van den Berg MM, Liem O, Benninga MA. The role of a probiotics mixture in the treatment of childhood constipation: a pilot study. Nutr J. 2007;6:17.

22. Pereira DIA, Mccartney AL, Gibson GR. An in vitro study of the probiotic potential of a bile-salt-hydrolyzing Lactobacillus fermentum strain, and determination of its cholesterol-lowering properties. Appl Environ Microb. 2003;69:4743-52.

23. Lee HS, Han SY, Bae EA, Huh CS, Ahn YT, Lee JH, Kim DH. Lactic acid bacteria inhibit proinflammatory cytokine expression and bacterial glycosaminoglycan degradation activity in dextran sulfate sodium-induced colitic mice. Int Immunopharmacol. 2008;8:574-80.

24. Sang-Yun Lee SY, Jeong JJ, Kim KA, Kim DH. Lactobacillus Sakei Ok67 ameliorates collagen-induced arthritis in mice by inhibiting NF-KB activation and restoring Th17/Treg cell balance. J Funct Foods. 2015;18:501-11.

25. Lee E, Jung SR, Lee SY, Lee NK, Paik HD, Lim S. Lactobacillus plantarum strain Ln4 attenuates diet-induced obesity, insulin resistance, and changes in hepatic mRNA levels associated with glucose and lipid metabolism. Nutrients. 2018;10:643.

26. Park S, Ji Y, Jung HY, Park H, Kang J, Choi SH, Shin H, Hyun CK, Kim KT, Holzapfel WH. Lactobacillus plantarum HACO1 regulates gut microbiota and adipose tissue accumulation in a diet-induced obesity murine model. Appl Microbiol Biotechnol. 2017;101:1605-14.

27. Bjørndal B, Burri L, Staalesen V, Skorve J, Berge RK. Different adipose depots: their role in the development of metabolic syndrome and mitochondrial response to hypolipidemic agents. J Obes. 2011;2011:490650.

28. DiBaise JK, Zhang H, Crowell MD, Krajmalnik-Brown R, Decker GA, Rittmann BE. Gut microbiota and its possible relationship with obesity. Mayo Clin Proc. 2008:83:460-9.

29. Koutnikova H, Genser B, Monteiro-Sepulveda M, Faurie JM, Rizkalla S, Schrezenmeir J, Clément K. Impact of bacterial probiotics on obesity, diabetes and non-alcoholic fatty liver disease related variables: a systematic review and meta-analysis of randomised controlled trials. BMJ Open. 2019;9(3):e017995.

30. Sivamaruthi BS, Kesika P, Suganthy N, Chaiyasut C. A review on role of microbiome in obesity and Antiobesity properties of probiotic supplements. Biomed Res Int. 2019;2019:3291367.

31. Ferrarese R, Ceresola ER, Preti A, Canducci F. Probiotics, prebiotics and synbiotics for weight loss and metabolic syndrome in the microbiome era. Eur Rev Med Pharmacol Sci. 2018;22:7588-605.

32. Zhao L. The gut microbiota and obesity: from correlation to causality. Nat Rev Microbiol. 2013;11:639-47.

33. Hummasti S, Hotamisligil GS. Endoplasmic reticulum stress and inflammation in obesity and diabetes. Circ Res. 2010;107:579-91.

34. Hotamisligil GS. Inflammation, metaflammation and immunometabolic disorders. Nature. 2017;542:177-85.

35. Fernández-Sánchez A, Madrigal-Santillán E, Bautista M, Esquivel-Soto J, Morales-González A, Esquivel-Chirino C, Durante-Montiel I, Sánchez-Rivera G, Valadez-Vega C, Morales-González JA. Inflammation, oxidative stress, and obesity. Int J Mol Sci. 2011;12:3117-32.

36. Furukawa S, Fujita T, Shimabukuro M, Iwaki M, Shimomura I. Increased oxidative stress in obesity and its impact on metabolic syndrome. J Clin Invest. 2004;114:1752-61

37. Blaser H, Dostert C, Mak TW, Brenner D. TNF and ROS crosstalk in inflammation. Trends Cell Biol. 2016;26:249-61.

38. Kotsis V, Antza C, Doundoulakis G, Stabouli S. Obesity, hypertension, and dyslipidemia. Springer International Publishing; 2017. p. 1-15.

39. Byrne CD. Ectopic fat, insulin resistance and non-alcoholic fatty liver disease. Proc Nutr Soc. 2013;72:412-9.

40. Moore KW, de Waal MR, Coffman RL, O'Garra A. Interleukin-10 and the interleukin-10 receptor. Annu Rev Immunol. 2001;19:683-765.
41. Egholm C, Heeb LEM, Impellizzieri D, Boyman O. The regulatory effects of Interleukin-4 receptor signaling on neutrophils in type 2 immune responses. Front Immunol. 2019;10:2507.

42. Paul WE, Ohara J. B-cell stimulatory factor-1/interleukin 4. Annu Rev Immunol. 1987;5:429-59.

43. Kotsis V, Antza C, Doundoulakis G, Stabouli S. Obesity, hypertension, and dyslipidemia. Springer International Publishing; 2017. p. 1-15.

44. Byrne CD. Ectopic fat, insulin resistance and non-alcoholic fatty liver disease. Proc Nutr Soc. 2013:72:412-19.

45. Zhu KX, Nie SP, Tan LH, Li C, Gong DM, Xie MY. A polysaccharide from ganoderma atrum improves liver function in type 2 diabetic rats via antioxidant action and short-chain fatty acids excretion. J Agric Food Chem. 2016;64:1938-44.

46. Birben E, Sahiner UM, Sackesen C, Erzurum S, Kalayci O. Oxidative stress and antioxidant defense. World Allergy Organ J. 2012;5:9-19.

47. Patel RM, Lin PW. Developmental biology of gut-probiotic interaction. Gut Microbes. 2010;1(3):186-95.

48. Thomas CM, Versalovic J. Probiotics-host communication: modulation of signaling pathways in the intestine. Gut Microbes. 2010;1(3):148-63.

49. Petrof EO. Probiotics and gastrointestinal disease: clinical evidence and basic science. Antiinflamm Antiallergy Agents Med Chem. 2009;8:260-9.

50. Zhao L. The gut microbiota and obesity: from correlation to causality. Nat Rev Microbiol. 2013:11(9):639-47.

51. Lu Y, Fan C, Li P, Lu Y, Chang X, Qi K. Short chain fatty acids prevent highfat-diet-induced obesity in mice by regulating $\mathrm{G}$ protein-coupled receptors and gut microbiota. Sci Rep. 2016;6:37589

52. Gross B, Pawlak M, Lefebvre P, Staels B. PPARs in obesity-induced T2DM dyslipidaemia and NAFLD. Nat Rev Endocrinol. 2017;13:36-49.

53. Madrazo JA, Kelly DP. The PPAR trio: regulators of myocardial energy metabolism in health and disease. J Mol Cell Cardiol. 2008;44:968-75.

54. Kersten $\mathrm{S}$, Stienstra R. The role and regulation of the peroxisome proliferator activated receptor alpha in human liver. Biochimie. 2017;136:75-84.

55. Janani C, Ranjitha Kumari BD. PPAR gamma gene--a review. Diabetes Metab Syndr. 2015;9:46-50

56. Li Y, Goto T, Yamakuni K, Takahashi N, Jheng HF, Nomura W, Taniguchi M, Baba K, Murakami S, Kawada T. 4-Hydroxyderricin, as a PPAR-y agonist, promotes adipogenesis, adiponectin secretion, and glucose uptake in 3T3L1 cells. Lipids. 2016:51:787-95.

57. Okuno M, Arimoto E, Nishizuka M, Nishihara T, Imagawa M. Isolation of upor down-regulated genes in PPARY-expressing $\mathrm{NIH}-3 \mathrm{~T} 3$ cells during differentiation into adipocytes. FEBS Lett. 2002;519:108-12.

58. Choi JS, Kim JH, Ali MY, Min BS, Kim GD, Jung HA. Coptis chinensis alkaloids exert anti-adipogenic activity on 3T3-L1 adipocytes by downregulating C/ EBP- $a$ and PPAR- $\gamma$. Fitoterapia. 2014;98:199-208.

59. Janssen AW, Betzel B, Stoopen G, Min BS, Kim GD, Jung HA. The impact of PPARa activation on whole genome gene expression in human precision cut liver slices. BMC Genomics. 2015:16:760.

60. Graham MJ, Lee RG, Brandt TA, Tai LJ, Fu W, Peralta R, Yu R, Hurh E, Paz E, McEvoy BW, Baker BF, Pham NC, Digenio A, Hughes SG, Geary RS, Witztum JL, Crooke RM, Tsimikas S. Cardiovascular and metabolic effects of ANGPTL3 antisense oligonucleotides. N Engl J Med. 2017;377:222-32.

61. Jambor de Sousa UL, Koss MD, Fillies M, Gahl A, Scheeder MR, Cardoso MC, Leonhardt H, Geary N, Langhans W, Leonhardt M. CPT1 alpha overexpression increases long-chain fatty acid oxidation and reduces cell viability with incremental palmitic acid concentration in 293T cells. Biochem Biophys Res Commun. 2005;338:757-761

62. Liu H, Pathak P, Boehme S, Chiang JY. Cholesterol 7a-hydroxylase protects the liver from inflammation and fibrosis by maintaining cholesterol homeostasis. J Lipid Res. 2016;57:1831-44.

63. Zhang J, Chen XL, Song JL, Qian Y. Preventive effects of Lactobacillus plantarum CQPCO7 on colitis induced by dextran sodium sulfate in mice. Food Sci Technol Res. 2019:25:413-23.

64. Peran L, Sierra S, Comalada M, Lara-Villoslada F, Bailón E, Nieto A, Concha A, Olivares M, Zarzuelo A, Xaus J, Gálvez J. A comparative study of the preventative effects exerted by two probiotics, Lactobacillus reuteri and Lactobacillus fermentum, in the trinitrobenzenesulfonic acid model of rat colitis, Br J Nutr. 2007:97:96-103.

\section{Publisher's Note}

Springer Nature remains neutral with regard to jurisdictional claims in published maps and institutional affiliations. 